\title{
DETERMINANTS OF DIVIDEND POLICY IN SRI LANKA: THE PANEL DATA ANALYSIS
}

\author{
Lingesiya Kengatharan \\ Department of Financial Management, \\ University of Jafna, Sri Lanka
}

\begin{abstract}
The study aimed to emphasize the determinants of dividend policy in Sri Lankan firms. This study was conducted with 80 non - financial companies which were listed on Colombo Stock Exchange (CSE). The empirical research was focused on panel data analysis, and data was collected from annual reports for a five year period from 2013 to 2017. This study explored selected factors that influence dividend policy, including sales growth, leverage, firm size, profitability, EPS, liquidity, and risk. The panel data analysis employed pooled OLS, fixed - effect, and random - effect models. Based on the analysis, the fixed - effect model was thought to be the best fit for studying the factors that affect dividend policy. According to the outcome of fixed-effect model, among the seven input variables considered in this study, profitability, EPS, and risk were negatively linked to dividend policy. However, no significant relationship was found between dividend policy and sales growth, leverage, firm size, or liquidity. The findings contribute to the understanding that three parameters namely: profitability, EPS, and risk have been recognized as factors affecting dividend payouts in CSE's listed companies. Hence, policymakers will be able to concentrate on the factors that influence shareholder wealth maximization.
\end{abstract}

Keywords: profitability, EPS, risk, dividend payout

\section{$\underline{\text { ARTICLE INFO }}$}

Article History:

Received: 2 October 2019

Accepted: 21 April 2021

Published: 31 August 2021

* Corresponding Author: Lingesiya Kengatharan. E-mail: lingesiya@yahoo.com 


\section{INTRODUCTION}

The dividend policy of a company is an essential aspect of its strategic financial planning. The term 'dividend policy' interprets the "management's practice in making dividend payout decisions, or, in other words, the size and pattern of cash dividends to shareholders over time" (Lease et al., 2000). The ultimate purpose of having a dividend policy is to capitalize on the prosperity of its owners (Khan \& Qureshi, 2018). The value of dividend payment to shareholders, the interval at which dividends are paid out, and what portion of profits is retained as retained earnings for business expansion are all determined by the dividend policy of a company.

Managers typically tend to keep earnings in an organization because retained earnings are essential to the growth of a company. If the shareholders are not paid dividends, the managers may begin to use these resources for their gain (Shah, Ullah, \& Hasnain, 2011). At the same time, rather than capital appreciation, shareholders prefer to receive dividends regularly. An issue with the agency has emerged in this case. As a result, dividend policy functions as a monitoring mechanism to ensure that conflicts of interest between owners and managers are reduced. (Ullah, Fida, \& Khan, 2012). Furthermore, a dividend policy will not only help to reduce agency costs but will also act as a signal to transfer the information to shareholders related to future profitability and firm valuation (Miller \& Rock, 1985). Increased dividends were thought to often increase market value before the Miller and Modigliani period. Miller and Modigliani (1961), emphasized that, for a given investment policy, dividends are irrelevant in deciding share value in an efficient capital market. As a result, in line with Miller and Modigliani (1961), the decision to pay a dividend has little effect on a firm's valuation. As a result, following the eras of Miller and Modigliani (1961) and Linter (1956), decisions over the dividend policy became one of the most contentious topics in corporate finance.

A significant amount of empirical and theoretical studies on dividend policy have been performed over the last few decades (i.e: Thakur \& Kannadhasan, 2018; Jaara, Alashhab, \& Jaara, 2018; Rehman, 2012; Mehta, 2012; Al-Malkawi, 2007). However, no consensus has yet been reached about why companies pay dividends, what significant factors affect corporate dividend policy, or how these factors influence policy. In 
the world of corporate finance, the true reason for paying dividends is a mystery (Baker \& Powell, 1999).

Sri Lanka is an emerging market (World Economic Outlook, 2017), comprising 290 listed companies covering 20 industries and a market capitalization of Rs. 2,797.91 billion as of July 31, 2019. To the best of my knowledge, there have been few studies that have analyzed the factors that influence dividend policy in Sri Lanka (i.e: Gunathilaka, 2012; Baker et al., 2019). As a result, this study enhances the existing body of knowledge by empirically identifying the determinants that influence non-financial firms' dividend payout decisions in Sri Lanka. The primary objective of this research was to look into the elements that influence the dividend policy of non - financial companies listed on the CSE. Accordingly, the research question was: What factors determine the dividend payout policy in Sri Lankan non-financial firms?

The following is the format of this paper: The literature review and hypotheses formulation are listed in section 2 . The study methods are discussed in Section 3. The empirical research findings are discussed in Section 4. The conclusions and implications taken from the findings are explained in Section 5.

\section{LITERATURE REVIEW AND FORMULATION OF HYPOTHESES}

The literature review of the study is composited with theories relating to dividend policy and empirical studies on the following.

\section{Theories on Dividend Policy}

\section{Theory of Modigliani \& Miller/ Modigliani - Miller Hypothesis}

In 1961, Miller and Modigliani (M\&M) developed a Nobel Prizewinning concept. They believed that the value of a company is determined by its earnings. Dividend payments are split between dividend payments and retention earnings. This has nothing to do with a firm's value. Therefore, they have concluded that dividend decisions are irrelevant as it does not affect shareholders' wealth. Assumptions underlying the M\&M theory are: 
capital markets are efficient, investors act rationally, information is readily available, there are no flotation costs, selling costs, taxes or tax rates applied to dividends and capital gains are the same, the business has a constant investment policy, and there is no risk of uncertainty.

\section{Bird in the hand theory}

Gordon proposed the Bird in the Hand Theory in 1963. Because of the ambiguity, this hypothesis emphasizes that investors choose the certainty of having cash on hand over capital gains in the future. Investors seek securities with high dividend payments and, as a result, a higher stock price, according to the bird-in-hand principle. This is because dividends have more certainty or less risk, which means that investors can discount the company's dividend at a lower return, resulting in a higher valuation of the company.

\section{Signalling theory}

According to $\mathrm{M} \& \mathrm{M}$, the variation in share price after an adjustment in dividend payment is because of the details found in the dividend payment, not merely based on the dividend payment itself. In other words, the adjustment in dividend payment can be viewed by shareholders and investors as a warning about the firm's potential earnings. A rise in dividend payment is generally regarded as a positive indicator, as it communicates positively about a company's potential earning prospects, leading to a rise in share price. A fall in dividend payment, on the other hand, is observed as a negative indicator regarding potential earning prospects, resulting in a drop in share price.

\section{Clientele effect}

Investors prefer a particular dividend yield; those in a high tax bracket would benefit from owning shares with a low dividend earning, while those in lower tax range would benefit from holding shares with a high dividend yield (Kalay, 1982). Individual investors have a higher marginal tax bracket than business investors, according to Allen and Michaely (2003), and business investors have a lower marginal tax range. They then showed that individual investors have low dividend payments and business investors have high dividend-paying shares.

\section{Agency cost theory}

The costs incurred in attempting to minimize the agency problems are referred to as agency costs. The agency problem arises from the possibility 
of objective disagreement in a principal-agent relationship. The principals in corporate finance are the shareholders who own the company, and managers serve as their agents. The agency problem for shareholders in a company where ownership is separated from managerial control is that managers in charge of day-to-day operations behave in their own best interests rather than those of the firm's owners, the shareholders.

When a company's owners implement policies and mechanisms aimed at mitigating the potential for conflict between managers' personal objectives and the company's objectives, they can incur agency costs. Incurring agency expenses decrease the valuation of a company's shares. In this case, the payment of dividends can have a possible influence on the company's valuation, at least in an indirect way. As a result, once the appropriate investment programs have been financed, the Agency Theory would mean that companies follow high dividend payout policies.

\section{Concept of Dividend Policy}

One of the most vital decisions made by firms on dividend policy is that whether they are going to pay out the profits as dividend payments or keep them as retained profits in the firms. Therefore, the dividend policy refers to the guiding principles by the firms to agree on how much profits are they going to distribute to the shareholders and how much profits they are going to keep in firms. Dividend policy conveys the information to the investors to make their investment decisions through the financial statements by indicating the dividend payout ratio, dividend yield, and dividend per share. There are four types of dividend policy exercise by firms which are regular dividend policy (regularly every year, a firm pays out dividends to its shareholders), irregular dividend policy (if a firm does not have steady cash flow they will practice irregular dividend policy), stable dividend policy (fixed amount of profit paid by the firm to shareholders as dividends) and no dividend policy (companies do not pay out profits to their shareholders). The majority of previous research considered the dividend policy as calculated by the dividend payout ratio (Linter, 1956; Denis \& Osobov, 2008; Al-Kuwari, 2009; Griffin, 2010; Maldajian \& Khoury, 2014). The dividend payout ratio takes into consideration the dividend payment and retention of dividends (Rafique, 2012). The dividend payout ratio is calculated by dividing the cash dividend divided by net profit. Therefore, the current study considered the dividend policy by calculating the dividend payout ratio. 


\section{Dividend payout $=\frac{\text { Dividend } \text { per } \text { share }}{\text { Earnings per share }}$}

There are few researches developed in Sri Lanka to investigate the determinants of dividend policy in Sri Lanka. Very recently Baker et al. (2019) carried out a study to examine the dividend policy determinants in Sri Lanka using the triangulation approach. The study used the data of 190 companies and survey data of 141 firms. Findings of the study based on the employed data revealed that firm size, industry impact, corporate governance, free cash flow, earnings, past dividends, profitability, investment opportunities, networking capital, concentrated ownership, and investor preferences were the determinants of dividend policy and then survey results based on a questionnaire validated these findings. Gunathilaka (2012) found the drivers of payout policy in Sri Lanka using a dynamic panel data analysis. He considered 82 listed companies data for a 5 year period from 2006 to 2010. Outcomes of his study revealed a negative relationship among the level of earnings and the probability of dividend distributions. Financial leverage and firm size have not shown any significant relationship with dividend payouts. Institutional shareholdings was identified as a determinant of payout which positively affected payouts. But, managerial ownership is negatively related to dividends. The current study tried the different predictor variables that have not been investigated previously in Sri Lanka which may also show an impact on dividend policy. The findings of this study would assist companies to manage their financial conditions which are useful to the firms for retaining and attracting valuable investors and also would be useful to investors to recognise important factors that determine the dividend payout ratio in Sri Lanka. Thus, the research intention was to identify the determinants of dividend policy for non-financial firms listed in Sri Lanka from 2013 to 2017. Variables considered in this study are discussed below:

\section{Sales growth}

Sales growth is identified as one of the most crucial factors that influence the dividend payout policy in firms. A majority of the researchers have suggested a positive relationship between sales growth and dividend payouts (i.e; Imran, 2011). Because, if sales increase profits will also increase. Increases in profits lead to a higher distribution to the shareholders. On the contrary, some other studies recommend that if firms have opportunities for investments in assets (i.e: expansion of existing projects) available income 
may be less to distribute to shareholders. Therefore, there is a significant negative relationship in- between sales growth and dividend payouts (Rozeff, 1982; Amidu \& Abor, 2006). Therefore, there are contradictions of opinions in the literature on the relationship between sales growth and dividend payouts. Thus, the following hypothesis was formulated

H1: There is a significant relationship between sales growth and dividend policy.

Sales growth can be calculated as follows:

$$
\text { Sales growth }=\frac{\text { current yearsales }- \text { previous year sales }}{\text { pervious year sales }} \times 100
$$

\section{Leverage}

A firm's leverage has also been treated as another significant factor in influencing a company's dividend policy. It is argued that a higher level of debt in the firm's capital structure will lead to a fixed amount of payment to the loan providers as interest from the profit. This will involve a high level of risk for an organization. Therefore, the researchers propose that a greater level of debt can create a less probability of giving cash dividends to owners. So it was concluded that there is a significant negative relationship in- between leverage and dividend payouts Rozeff (1982). This outcome is in line with the Agency Cost Theory of dividend policy. The findings of Rozeff (1982) are consistent with the study of Al-Malkawi (2007), which states a significant and negative relationship between leverage and dividend pay outs.

Even though, the results of the study of Kania and Bacon (2005) contradicted with the findings of Rozeff (1982) and Al-Malkawi (2007) that there is a significant positive relationship between debt level and dividend payments. Still, there is no clear evidence available in the literature to illustrate the relationship between leverage and dividend payouts. The present study hypothesized as follows:

H2: There is a significant relationship between leverage and dividend policy 
Leverage is measured as total debt value divided by total assets value:

$$
\text { Leverage }=\frac{\text { Total debt }}{\text { Total assets }}
$$

\section{Firm Size}

There is a thought in the financial literature that huge firms can make convenient access in the capital markets and they can be able to appoint separate expert/s in formulating the policy frameworks (i.e: dividend policy) to maximize shareholders' wealth, make sure of the financial sustainability and survival of firms. If the large companies need finance, they won't be able to depend on the internally created funds as they can deal with capital markets.

Therefore, empirical studies produce evidence that there is a strong positive relationship available between firm size and dividend payouts (Eddy \& Seifert, 1988; Eriotis, 2005; Jensen, Solberg, \& Zorn, 1992; Redding, 1997; Fama \& French, 2000; and Lloyd, Jahera, \& Page, 1985). Another argument in the literature is that large firms pay higher amounts of dividends to reduce agency costs (Ghosh \& Woolridge, 1988; Jensen et al., 1992; Holder, Langrehe, \& Hexter, 1998; Al-Malkawi, 2007; Al Kuwari, 2009; Juhmani, 2009; Imran, 2011; Al-Shabibi \& Ramesh, 2011; Osman $\&$ Mohammed, 2010). Therefore, the current study tried to identify the relationship between firm size and dividend payouts. Thus, it is hypothesized as:

H3: There is a significant relationship between firm size and dividend policy

$$
\text { Firm size }=\log (\text { total sales })
$$

\section{Profitability}

The profitability of a firm has been regarded as one the most important determinant of dividend policy of a firm in the finance literature. Present earnings of a firm and its history on dividends influenced the dividend payment pattern of a firm (Linter, 1956). Similar findings have been observed 
by Baker and Powell (2001). Ling, Mutalip, and Shahrin (2008) examined the function of dividend payout focusing on 100 firms in Malaysia. They found that Return on Assets (ROA) and Return on Equity (ROE) have a significant impact on dividend pay-out. Aivazian, Booth, and Cleary (2003) studied the dividend policies in U.S. firms. They concluded that profitability influenced dividend payments and found a significant negative relationship between debt ratio and dividend payout, and market-to-book ratio also showed a positive relationship with dividend payments. Al-Malkawi (2007) and Adil, Zafar, and Yaseen (2011) indicated in their studies that profitability is another major factor in determining the dividend payout policy. Malik et al. (2013) analysed the elements that determine the dividend policy with 100 companies listed on the Karachi Stock Exchange. Panel data which was derived from annual reports of the selected firms from 2007 to 2009 was used to conduct the empirical study. The results of the study expressed that there was a significant positive relationship of liquidity, leverage, earning per share, and size of the firm with dividend payouts, whereas sales growth and profitability, did not shown any significant relationship with dividend payouts.

Gill, Bigger, and Tibrewala (2010) found the determinants of dividend policy of US firms and explained that firms' dividend policies differed among the different types of industries. For instance, the results of their study say profitability harmed dividend payouts in the manufacturing industry. This result was in line with the results of DeAngelo, DeAngelo, and Stulz (2006). However, the findings of the study of Anil and Kappor (2008) contradicted with Ravindran and Kengatharan (2020), and Gill et al. (2010) which showed no significant impact between profitability and dividend policy. Even though, studies of Al-Ajmi and Abo Hussain (2011), Alam and Hossain (2012), Denis and Osobov (2008), and Rehman and Takumi (2008) suggested that profitability was significantly and positively related to dividend payouts. The present study considered the profitability as calculated by ROA (Fitri, Hosen, \& Muhari, 2016; Mehta, 2012; Amidu $\&$ Abor, 2006). Therefore, the findings from the empirical studies are mixed and thus the present study hypothesized that:

H4: Profitability is significantly related to dividend policy 
ROA is calculated as follows:

$$
R O A=\frac{E B I T}{\text { Total Assets }}
$$

\section{Earnings Per Share (EPS)}

Issa (2015) investigated the determinants that influenced the dividend pay - out ratio with 284 listed Malaysian firms on the Kuala Lumpur Stock Exchange. Profitability, firm size, growth opportunities, cash flow, business risks, market capitalization, and market to book value were investigated to determine if they influenced dividend payout. Results of the study revealed that free cash flow, return on assets, return on equity, earning per share, market to book value and market capitalization had a significant positive association with the dividend payout ratio while business risk had a negative connection on dividend pay-out ratio. Studies of Imran (2011); Alzomaia and Al-Khadhiri (2013) suggested that earnings per share showed a positive relationship on dividend policy. Malik et al. (2013) are also found that EPS was significantly related to dividend payouts. Based on these empirical results of the previous research, the following hypothesis was formulated in this study:

H1: There is a significant relationship between earnings per share and dividend policy

$$
E P S=\frac{\text { Net profit for ordinary shareholder }}{\text { no of ordinary shares outstanding }}
$$

\section{Liquidity}

Dividend payments are highly dependent on cash flows, which indicate a company's capability to disburse dividends. A weak liquidity position means lower liberal dividends due to cash flow (Ahmed \& Javid 2009). If a company is in a good cash position it can direct larger levels of dividend payments because the availability of money in the firm is high. Therefore, researchers have suggested a positive correlation between liquidity positions and decisions over dividend payment (Ho, 2003; Amidu \& Abor, 2006; Anil \& Kapoor, 2008; Ahmed \& Javid, 2009). This aligns with the Signaling 
Theory. A negative correlation between liquidity and dividend policy was observed by Griffin in 2010. The present study hypothesized that:

H6: There is a significant relationship between liquidity and dividend policy

The liquidity of the firm is calculated as follows:

$$
\text { Liquidity }=\frac{\text { Current Assets }}{\text { Current liabilities }}
$$

\section{Risk}

The $\mathrm{P} / \mathrm{E}$ ratio, can be measured by dividing the price of a share by earnings per share, which is a risk indicator. The $\mathrm{P} / \mathrm{E}$ ratio takes into account the probability of a company's potential earnings. Investors will expect higher dividends as profits in the future if the P/E ratio is high (Fama \& French, 1998). A large amount of cash dividends will reduce the risk of potential cash flow to stockholders, resulting in an improvement in stock price and the $\mathrm{P} / \mathrm{E}$ ratio. A high $\mathrm{P} / \mathrm{E}$ ratio indicates a lower level risk, which leads to higher payout ratios, while a low $\mathrm{P} / \mathrm{E}$ ratio indicates high level risk, which leads to lower payout ratios Amidu and Abor (2006). Therefore it was hypothesised that:

H7: There is a significant relationship between risk and dividend policy

The formula for the $\mathrm{P} / \mathrm{E}$ ratio is given below:

$$
P / \text { E ratio }=\frac{\text { Price of share }}{E P S}
$$

\section{METHODS}

The study's target population was 290 CSE-listed companies as of July 2019. Banking, finance, and insurance companies were excluded from the current study because of their distinct financial characteristics, the severity of directives, laws, and regulations, and the formation of capital structures in 
comparison to non-financial firms. Furthermore, newly listed non-financial businesses and non-dividend paying companies were excluded from the study. Following the elimination, 80 firms were considered as a sample for constructing the strong panel data for the years 2013-2017. The audited financial reports of the selected firms, which were available on the CSE's website, was the source of data.

\section{Models Specifications}

This study examined 80 non-financial firms with 400 observations using panel data collected from 2013 to 2017 to determine the determinants of dividend policy amongst Sri Lankan listed non-financial companies. Individual/group effects, time effects, or both exist in panel data, which can be investigated using a fixed - effect or random - effect model. To begin, a pooled OLS analysis was used to determine the determinants of dividend policy amongst Sri Lankan non-financial companies. The fixed effect model was used second, and the random - effect model was used third. The proposed models are presented below:

1. Pooled OLS models

$\mathrm{DPR}_{\mathrm{it}}=\alpha_{0}+\alpha_{1} \mathrm{SG}_{\mathrm{it}}+\alpha_{2} \mathrm{LEV}_{\mathrm{it}}+\alpha_{3} \mathrm{FS}_{\mathrm{it}}+\alpha_{4} \mathrm{PROF}_{\mathrm{it}}+\alpha_{5} \mathrm{EPS}_{\mathrm{it}}+\alpha_{6} \mathrm{LIQ}_{\mathrm{it}}+$ $\alpha_{7} \operatorname{Risk}_{\mathrm{it}}+\varepsilon_{\mathrm{it}}$

2. Fixed Effect Models

$\mathrm{DPR}_{\mathrm{it}}=\alpha_{0}+\alpha_{1} \mathrm{SG}_{\mathrm{it}}+\alpha_{2} \mathrm{LEV}_{\mathrm{it}}+\alpha_{3} \mathrm{FS}_{\mathrm{it}}+\alpha_{4} \mathrm{PROF}_{\mathrm{it}}+\alpha_{5} \mathrm{EPS}_{\mathrm{it}}+\alpha_{6} \mathrm{LIQ}_{\mathrm{it}}+$ $\alpha_{7} \operatorname{Risk}_{\mathrm{it}}+\mathrm{u}_{\mathrm{it}}$

3. Random Effect Models

$\mathrm{DPR}_{\mathrm{it}}=\alpha_{0}+\alpha_{1} \mathrm{SG}_{\mathrm{it}}+\alpha_{2} \mathrm{LEV}_{\mathrm{it}}+\alpha_{3} \mathrm{FS}_{\mathrm{it}}+\alpha_{4} \mathrm{PROF}_{\mathrm{it}}+\alpha_{5} \mathrm{EPS}_{\mathrm{it}}+\alpha_{6} \mathrm{LIQ}_{\mathrm{it}}+$ $\alpha_{7} \operatorname{Risk}_{\mathrm{it}}+\mathrm{u}_{\mathrm{it}}+\varepsilon_{\mathrm{it}}$

In the equation,

$D P R_{i t}$ is dividend pay - out ratio of firm $i$ at time $t$.

$S G_{i t}$ is sales - growth of firm $i$ at time $t$.

$L E V_{i t}$ is the leverage of firm $i$ at time $t$

$F S_{i t}$ is the log of total sales for firm $i$ in time $t$;

$\mathrm{PROF}_{i t}$ is Return on Assets of a firm $i$ at time $t$ 
$E P S_{i t}$ is earnings per share of firm $i$ at time $t$.

$L I Q_{i t}$ is liquidity of firm $i$ at time $t$.

$P E_{i t}$ is price earnings ratio of firm $i$ at time $t$.

$\alpha_{0}$ - intercept coefficient of firm I;

$\alpha_{1}, \alpha_{2}, \alpha_{3}, \alpha_{4}, \alpha_{5}, \alpha_{6} \& \alpha_{7}$-row vectors of slope coefficient of regressors

$\varepsilon_{i t}$ : Stochastic error term of firm $i$ at time $t$

$u_{i t}$ : error term of firm $i$ at time $t$

\section{RESULTS AND DISCUSSIONS}

\section{Descriptive Analysis}

Table 1 describes the descriptive statistics summary of variables considered in the study.

Table 1: Summary of Descriptive Statistics

\begin{tabular}{lccccc}
\hline \multicolumn{1}{c}{ Variables } & Obs & Mean & St.Dev. & Minimum & Maximum \\
\hline Sales Growth & 400 & 7.1982 & 18.4488 & -99.4560 & 83.1315 \\
Leverage & 400 & .3585 & .2158 & .0099 & .9702 \\
Firm Size & 400 & 9.7724 & .4708 & 8.6055 & 11.1544 \\
Profitability (ROA) & 400 & 11.8536 & 10.3375 & -7.5405 & 90.8530 \\
EPS & 400 & 11.3034 & 63.0452 & -974.6411 & 211.2108 \\
Liquidity & 400 & 3.5260 & 6.7709 & .0678 & 55.5992 \\
Risk & 400 & 16.3964 & 46.4369 & -396.6173 & 357.2471 \\
Dividend Payout & 400 & .5365 & 1.2208 & -7.6272 & 12.9908 \\
\hline
\end{tabular}

As in Table 1, the mean value of sales growth was 7.1982. Sales growth ranged from -99.4560 to 83.1315 . Leverage ranged from 0.0099 to 0.9702 and the mean value was 0.3585 with a deviation of .02158 . The value of mean for firm size was 9.7724 with the minimum value at 8.6055 and the maximum value at 11.1544. ROA ranged from -7.5405 to 90.8530 and the mean value was 11.8536 with a standard deviation of 10.3375. EPS, Liquidity, and Risk had the mean values of $11.3034,3.5260$, and 16.3964 respectively. The dividend payout ratio had 0.5365 which ranged from -7.6272 to 12.9908 . 
Table 2: Correlation Analysis

\begin{tabular}{|c|c|c|c|c|c|c|c|c|}
\hline & SG & LEV & FS & PROF & EPS & LIQ & RISK & DPR \\
\hline \multirow[t]{2}{*}{ SG } & 1.0000 & & & & & & & \\
\hline & ---- & & & & & & & \\
\hline \multirow[t]{2}{*}{ LEV } & $0.1494^{*}$ & 1.0000 & & & & & & \\
\hline & 0.0027 & & & & & & & \\
\hline \multirow[t]{2}{*}{ FS } & -0.0009 & $0.1260^{*}$ & 1.0000 & & & & & \\
\hline & 0.9850 & 0.0117 & & & & & & \\
\hline \multirow[t]{2}{*}{ PROF } & 0.0739 & -0.0306 & -0.0063 & 1.0000 & & & & \\
\hline & 0.1402 & 0.5416 & 0.9008 & & & & & \\
\hline \multirow[t]{2}{*}{ EPS } & 0.0465 & -0.0770 & 0.0254 & $0.1545^{*}$ & 1.0000 & & & \\
\hline & 0.3537 & 0.1244 & 0.6132 & 0.0019 & & & & \\
\hline \multirow[t]{2}{*}{ LIQ } & -0.0326 & $-0.4355^{*}$ & 0.0779 & 0.0239 & 0.0659 & 1.0000 & & \\
\hline & 0.5151 & 0.0000 & 0.1197 & 0.6341 & 0.1881 & & & \\
\hline \multirow[t]{2}{*}{ RISK } & 0.0215 & -0.0721 & -0.0054 & -0.0173 & 0.0623 & -0.0153 & 1.0000 & \\
\hline & 0.6687 & 0.1501 & 0.9150 & 0.7305 & 0.2135 & 0.7600 & & \\
\hline \multirow[t]{2}{*}{ DPR } & -0.0212 & -0.0433 & -0.0232 & 0.0460 & -0.0032 & -0.0232 & $0.6618^{*}$ & 1.0000 \\
\hline & 0.6720 & 0.3878 & 0.6440 & 0.3587 & 0.9484 & 0.6442 & 0.0000 & \\
\hline
\end{tabular}

As per the findings of the correlation analysis presented in Table 2, the dividend payout ratio was not significantly associated with variables considered in this study except risk measure. Risk was measured using the $\mathrm{P} /$ E ratio in this study. Therefore, there was a significant positive relationship between the $\mathrm{P} / \mathrm{E}$ ratio and dividend payout ratio $(\mathrm{r}=0.6618, \mathrm{p}=0.0000)$. It means that if the $\mathrm{P} / \mathrm{E}$ ratio is high risk will be lower. Therefore, a negative association existed between risk and dividend payouts. However, sales growth $(r=-0.0212, P>0.05)$, leverage $(r=-0.0433, P>0.05)$, firm size $(\mathrm{r}=-0.0232, \mathrm{P}>0.05)$, profitability $(\mathrm{ROA})(\mathrm{r}=0.0460, \mathrm{P}>0.05)$, EPS $(\mathrm{r}=$ $-0.0032, \mathrm{P}>0.05)$ and liquidity $(\mathrm{r}=-0.0232, \mathrm{P}>0.05)$ were not significantly correlated with dividend payout ratio. If the correlations between a couple of response variables are strong, the regression model's results may be skewed. To notice multi-collinearity, many regression analysts used variance inflation factors. As a result, the variable inflation factor test was used in this empirical analysis to find out if multi-collinearity existed between the predictor variables. 
Table 3: Summary Values of Variance Inflation Factors

\begin{tabular}{|c|c|c|}
\hline Variable & VIF & $1 / \mathrm{VIF}$ \\
\hline LEV & 1.32 & 0.7564 \\
\hline LIQ & 1.27 & 0.7880 \\
\hline FS & 1.04 & 0.9605 \\
\hline EPS & 1.04 & 0.9630 \\
\hline SG & 1.03 & 0.9663 \\
\hline PROF & 1.03 & 0.9698 \\
\hline $\mathrm{P} / \mathrm{E}$ & 1.01 & 0.9866 \\
\hline Mean VIF & 1.11 & \\
\hline
\end{tabular}

Empirical studies have suggested that a value of less than 10 is acceptable in statistics (Nachane, 2006). As per the results of VIF presented in Table 3, this study did not identify any problems.

Table 4: Determinants of Dividend Payout Ratio

\begin{tabular}{|c|c|c|c|}
\hline Variable & Pooled & Fixed effect & $\begin{array}{c}\text { Random } \\
\text { effect }\end{array}$ \\
\hline & (Coef) & (Coef) & (Coef) \\
\hline C & 0.6351 & 0.2062 & 0.6610 \\
\hline Sales Growth (SG) & -0.0026 & -0.0015 & -0.0023 \\
\hline Leverage (LEV) & 0.0443 & -0.3748 & 0.0395 \\
\hline Firm Size (FS) & -0.0474 & 0.0421 & -0.0465 \\
\hline Profitability (PROF) & $0.0081^{*}$ & $-0.0195^{* *}$ & 0.0049 \\
\hline EPS & -0.0010 & $-0.0020^{* *}$ & $-0.0012^{*}$ \\
\hline Liquidity (LIQ) & -0.0014 & 0.0035 & -0.0011 \\
\hline Risk (P/E) & $0.0175^{\star \star *}$ & $0.1862^{\star * *}$ & $0.0178^{* * *}$ \\
\hline No. of obs & 400 & 400 & 400 \\
\hline $\mathrm{R}^{2}$ & 0.4464 & 0.4862 & 0.4988 \\
\hline F-statistic of the model ( $F$ value, $\mathrm{P}$-value) & $45.10(0.000)$ & $42.31(0.000)$ & $10.32(0.027)$ \\
\hline $\begin{array}{l}\text { F Test } \\
\text { (Pooled VS Fixed) }\end{array}$ & & $1.70(0.0008)$ & \\
\hline $\begin{array}{l}\text { Breush \& Pegan Lagrange Multiplier Test } \\
\text { (Pooled VS Random) }\end{array}$ & & & $5.23(0.0111)$ \\
\hline $\begin{array}{l}\text { Hausman Specification Test } \\
\text { (Fixed Vs Random) }\end{array}$ & & $25.50(0.0006)$ & \\
\hline
\end{tabular}


The findings of a panel data study to determine the determinants of dividend payment policy in listed non-financial firms in Sri Lanka are shown in Table 4. To determine the most suitable model to describe the determinants of dividend policy in Sri Lanka, researchers used a pooled OLS, fixed - effect model, and random - effect model. The F-statistics and $\mathrm{p}$-values of the pooled OLS model $(\mathrm{F}=45.10$ and $\mathrm{P}<0.01)$, fixed - effect model $(\mathrm{F}=42.31, \mathrm{P}<0.01)$, and random - effect model $(\mathrm{F}=10.32$ and $\mathrm{P}<$ $0.05)$ indicated that all three models are important in describing variations in Sri Lanka's dividend policy.

In this analysis, independent variables included sales growth, leverage, firm size, profitability, EPS, liquidity, and risk. In the pooled, fixed, and random effects models, the values of $\mathrm{R}^{2} 0.4464,0.4862$, and 0.4988 indicated that all seven predictor variables together account for around 44.64 percent, 48.62 percent, and 49.88 percent variation in dividend policy, respectively. In any case, one model should be chosen as the most suitable in order to reach a conclusion.

The $\mathrm{F}$ test was used to detect the time fixed effect in a fixed - effect model, with a $\mathrm{p}$ value of less than 0.05 as the result. As a result, the null hypothesis (null: no fixed effect, alternative $=$ fixed effect exists) that there are time fixed effects in the model was rejected. The random effect was also tested using the Breush and Pegan Lagrange Multiplier Test. The probability value was 0.0111 , indicating that the null hypothesis (null: no random effect, alternative $=$ random effect exists) was rejected in favour of the alternative, implying that the random effect model is more suitable than the pooled OLS.

The Hausman Test was employed to assess which of the two alternative panel analysis models, fixed effect or random effect, should be used. The null hypothesis that variations in coefficients of fixed and random estimates were not systematic was rejected using the Hausman test statistics (25.50, $\mathrm{P}<0.05)$, indicating that embracing and interpreting the fixed effect model is most fitting in this analysis. In this scenario, the most appropriate model to describe the determinants of dividend policy in Sri Lankan non-financial firms from 2013 to 2017 is the fixed - effect model. 
According to the results presented for the fixed - effect model as in Table 4 , showed a significant negative relationship of profitability $(\alpha=$ $-0.0195, \mathrm{P}<0.05)$ and EPS $(\alpha=-0.0020, \mathrm{P}<0.05)$ with dividend payout ratio. However, $\mathrm{P} / \mathrm{E}$ ratio $(\alpha=0.1862, \mathrm{P}<0.01)$ was significantly positively related to dividend payout ratio. Sales growth, leverage, firm size, and liquidity were not significantly correlated to the dividend payout policy in the present study. Thus, $\mathrm{H}_{1}, \mathrm{H}_{2}, \mathrm{H}_{3}$ and $\mathrm{H}_{6}$ were not supported by the findings of the study and they were not significantly related to dividend payout. As profitability (ROA) and EPS are significantly negatively related to dividend payout ratio. $\mathrm{H}_{4}$ and $\mathrm{H}_{5}$ were supported by the findings of the study and profitability and EPS were significantly negatively correlated to the dividend payouts ratio. There is a general argument in the literature that more profitable companies distribute larger amounts of dividends compared to lower profitable firms. Profitable firms create the ability to pay dividends.

Researchers have suggested that there is a significant positive relationship between profitability and dividend payouts (e.g: Al-Kuwari, 2009; Al-Ajmi \& Hussain, 2011; Alam \& Hossain, 2012; Denis \& Osobov, 2008 and Rehman \& Takumi, 2008; Baker et al., 2019). Also, some other researchers have concluded that there is no significant relationship between profitability and dividend policy (Ravindran \& Kengatharan, 2020; Mehta, 2012; Malik et al., 2013). Therefore, the findings of the study contradict the above studies as profitability was significantly and negatively related to dividend policy in this study and consistent with the findings of Amidu and Abor (2006); Maldajian and Khoury (2014).

EPS was also significantly negatively related to dividend policy in this study and this result contradicts Mehta (2012), Alzomaia and Al-Khadhiri (2013), Issa (2015), Baker et al. (2019) as they all suggest a positive relationship.

Risk measure of $\mathrm{P} / \mathrm{E}$ ratio was positively significantly related to dividend payout ratio. Therefore, $\mathrm{H} 7$ was supported by the results of the study. Findings of the study explain that a high $\mathrm{P} / \mathrm{E}$ ratio implies a lower risk and higher dividend payouts. On the other hand, a lower $\mathrm{P} / \mathrm{E}$ ratio indicates high risks and lower dividend payouts. So, it can be decided that risk has a negative association with dividend payouts. The findings of the study are consistent with Fama and French (1998) and Amidu and Abor (2006). 
Sales growth has not shown any significant impact on dividend policy in this study. Therefore, the findings of this study contradict Higgins (1972); Manos (2002); and Rozeff (1982) as they have suggested a negative relationship between sales growth and dividend payouts.

It is reported in the literature that there is a positive relationship between leverage and dividend policy (Kania \& Bacon, 2005), and a negative relationship has been identified by Al-Malkawi (2007) and Rozeff (1982). Even though the results of the present study contradict with this literature that there is no significant relationship, the results are however consistent with the findings of Mehta (2012) and one of the Sri Lankan studies by Gunathilaka (2012).

Further, it was identified that there was no significant relationship between firm size and dividend payout policy in this study, and this finding contradicts Baker et al. (2019); Brawn and Šević (2018), and Al-Kuwari (2009) because they identified a positive relationship. But these findings are consistent with the results of the previous Sri Lankan study of Gunathilaka (2012).

Liquidity did not express any significant relationship with dividend policy in this study. This result was consistent with Mehta (2012) and contradicts with some other studies (Amidu \& Abor, 2006; Griffin, 2010; Anil \& Kapoor, 2008; Ahmed \& Javid, 2009). According to the output presented from the fixed-effect model as in Table 4 , the value of the coefficient of determination of all dimensions considered in this study $\left(\mathrm{R}^{2}=.4862\right)$ around $49 \%$ of the total variance of dividend payout ratio was determined by sales growth, leverage, firm size, profitability, EPS, liquidity and $\mathrm{P} / \mathrm{E}$ ratio. Regardless, only three of the seven predictor variables considered in this analysis, namely profitability, EPS, and P/E ratio, determined the dividend policy in this study. This is the response to the study's research question. 


\section{CONCLUSION, IMPLICATIONS, AND DIRECTIONS FOR THE FUTURE RESEARCH}

The present study looked at the factors that influenced dividend policy in Sri Lankan listed non-financial companies. The empirical research was based on 80 firms' panel data from 2013 to 2017. Results of the study showed that profitability (ROA), EPS, and risk were significantly negatively related to dividend payout ratio. The findings of the study contributed to the knowledgebase especially to the emerging markets as the factors determining dividend policy were identified. Policymakers should pay attention to the factors that influence shareholder's wealth maximization. Further research into the various predictor variables that may affect dividend policy is recommended in the future. Furthermore, conducting similar studies with different samples than those used in this analysis would add to the overall research on dividend payout decisions.

\section{REFERENCES}

Adil, C. M., Zafar N., \& Yaseen, N. (2011). Empirical analysis of determinants of dividend payout: Profitability and liquidity. Interdisciplinary Journal of Contemporary Research in Business, 3(1), 289-300.

Ahmed, H., \& Javid, A. (2008). The determinants of dividend policy in Pakistan. International Research Journal of Finance and Economics, 29(1), 110-125.

Aivazian, V., Booth, L., \& Cleary, S. (2003). Do emerging market firms follow different dividend policies from U.S. firms? Journal of Financial Research, 26(3), 371-387.

Al-Ajmi, J., \& Abo Hussain, H. (2011). Corporate dividends decisions: Evidence from Saudi Arabia. The Journal of Risk Finance, 12(1), 41-56.

Alam, M. Z., \& Hossain, M. E. (2012). Dividend policy: A comparative study of UK and Bangladesh based companies. IOSR Journal of Business and Management, 1(1), 57-67. 
Al-Kuwari, D. (2009). Determinants of the dividend policy of companies listed on emerging stock exchanges: The case of the Gulf Cooperation Council (GCC) countries. Global Economy \& Finance Journal, 2(2), 38-63.

Al-Kuwari, D. (2010). Large shareholders, agency theory and dividend decision in emerging markets. Emerging Markets Economics: Firm Behavior \& Microeconomic Issues eJournal. Available at SSRN https:// ssrn.com/abstract $=1811845$

Allen, F., \& Michaely, R. (2003). Payout policy. In G. Constantinides, M. Harris, \& Stulz, R. (Eds.), Handbook of the economics of finance (pp. 337-429). Amsterdam: Elsevier.

Al-Malkawi, H. A. N. (2007). Determinants of corporate dividend policy in Jordan: An application of the Tobit model. Journal of Economic \& Administrative Sciences, 23(2), 44-70.

Al-Shabibi, B. K., \& Ramesh, G. (2011). An empirical study on the determinants of dividend policy in the UK. International Research Journal of Finance and Economics, 80(12), 105-124.

Alzomaia, T. S., \& Al-Khadhiri, A. (2013). Determination of dividend policy: The evidence from Saudi Arabia. International Journal of Business and Social Science, 4(1), 181-192.

Amidu, M., \& Abor, J. (2006). Determinants of dividend payout ratios in Ghana. The Journal of Risk Finance, 7(2), 136-145.

Anil, K., \& Kapoor, S. (2008). Determinants of dividend payout and ratios A study of Indian information technology sector. International Research Journal of Finance and Economics, 15(15), 63-71.

Baker, H. K., \& Powell, G. E. (1999). How corporate managers view dividend policy. Quarterly Journal of Business and Economics, 38(2), 17-35. 
Baker, H. K., Dewasiri, N. J., Yatiwelle Koralalage, W. B., \& Azeez, A. A. (2019). Dividend policy determinants of Sri Lankan firms: A triangulation approach. Managerial Finance, 45(1), 2-20.

Baker, H. K., Veit, E. T., \& Powell, G. E. (2001). Factors influencing dividend policy decisions of Nasdaq firms. Financial Review, 36(3), 19-38.

Brawn, D. A., \& Šević, A. (2018). Firm size matters: Industry sector, firm age and volatility do too in determining which publicly-listed US firms pay a dividend. International Review of Financial Analysis, 58(C), 132-152.

DeAngelo, H., DeAngelo, L., \& Stulz, R. M. (2006). Dividend policy and the earned/contributed capital mix: A test of the life-cycle theory. Journal of Financial Economics, 81(2), 227-254.

Denis, D. J., \& Osobov, I. (2008). Why do firms pay dividends? International evidence on the determinants of dividend policy. Journal of Financial Economics, 89(1), 62-82.

Eddy, A., \& Seifert, B. (1988). Firm size and dividend announcements. Journal of Financial Research, 11(4), 295-302.

Eriotis, N. (2005). The effect of distributed earnings and size of the firm to its dividend policy: Some Greek data. International Business \& Economics Journal, 4(1), 67-74.

Fama, E. F., \& French, K. R. (1998). Value versus growth: The international evidence. The Journal of Finance, 53(6), 1975-1999.

Fama, E. F., \& French, K. R. (2000). Forecasting profitability and earnings. The Journal of Business, 73(2), 161-175.

Fitri, R. R., Hosen, M. N., \& Muhari, S. (2016). Analysis of factors that impact dividend payout ratio on listed companies at Jakarta Islamic index. International Journal of Academic Research in Accounting, Finance and Management Sciences, 6(2), 87-97. 
Ghosh, C., \& Woolridge, J. R. (1988). An analysis of shareholder reaction to dividend cuts and omissions. Journal of Financial Research, 11(4), 281-294.

Gill, A., Bigger, N., \& Tibrewala, R. (2010). Determinants of dividend payout ratios: Evidence from United States. The Open Business Journal, 3(1), 8-14.

Gordon, M. J. (1963). Opitmal investment and financing policy. The Journal of Finance, 18(2), 264-272.

Griffin, C. H. (2010). Liquidity and dividend policy: International evidence. International Business Research, 3(3), 3-9.

Gunathilaka, C. (2012). What drives the payout policy? Evidence from Sri Lanka: A dynamic panel data analysis. Wajamba Journal of Management, 3(2), 1-16.

Higgins, R. C. (1972). The corporate dividend - Saving decisions. Journal of Financial and Quantitative Analysis, 7(2), 1527-1541.

Ho, H. (2003). Dividend policies in Australia and Japan. International Advances in Economic Research, 9(2), 91-100.

Holder, M. E., Langrehr, F. W., \& Hexter, J. L. (1998). Dividend policy determinants: An investigation of the influences of stakeholder theory. Financial Management, 27(3), 73-82.

Imran, K. (2011). Determinants of dividend payout policy: A case of Pakistan engineering sector. The Romanian Economic Journal, 41(14), 47-59.

Issa, A. (2015). The determinants of dividend policy: Evidence from Malaysian firms. Research Journal of Finance and Accounting, 6(18), 69-86.

Jaara, B., Alashhab, H., \& Jaara, O. O. (2018). The determinants of dividend policy for non-financial companies in Jordan. International Journal of Economics and Financial Issues, 8(2), 198-209. 
Jensen, G. R., Solberg, D. P., \& Zorn, T. S. (1992). Simultaneous determination of insider ownership, debt, and dividend policies. The Journal of Financial and Quantitative Analysis, 27(2), 247-263.

Juhmani, O. I. H. (2009). Determinants of dividend payout policy: Evidence from Bahraini firms. Journal of International Finance and Economics, $9(2), 77-86$.

Kalay, A. (1982). The ex-dividend day behavior of stock prices: A reexamination of the clientele effect. The Journal of Finance, 37(4), 1059-1070.

Kania, S., \& Bacon, F. (2005). W. (2005). What factors motivate the corporate dividend decision. American Society of Business and Behavioural Sciences E-Journal, 1(1), 97-107.

Khan, A. B., \& Qureshi, N. Z. (2018). Does dividend policy affect shareholders' wealth? International Journal of Current Engineering and Scientific Research, 5(2), 1-7.

Lease, R. C., John, K., Kalay, A., Loewenstein, U., \& Sarig, O. H. (2000). Dividend policy: Its impact on firm value. Boston, Massachusetts: Harvard Business School Press.

Ling, F. S., Mutalip, M. L. A., \& Shahrin, A. R. (2008). Dividend policy: Evidence from public listed companies in Malaysia. International Review of Business Research Papers, 4(4), 208-222.

Linter, J. (1956). Distribution of incomes of corporations among dividends, retained earnings, and taxes. The American Economic Review, 46(2), 97-113.

Lloyd, W. P., Jahera, J. S., \& Page, D. E. (1985). Agency costs and dividend payout ratios. Quarterly Journal of Business and Economics, 24(3), 19-29.

Maldajian, C., \& Khoury, R. E. (2014). Determinants of the dividend policy: An empirical study on the Lebanese listed banks. International Journal of Economics and Finance, 6(4), 240-256. 
Malik, F., Gul, S., Khan, M. T., Rehman, S. U., \& Khan, M. (2013). Factors influencing corporate dividend payout decisions of financial and nonfinancial firms. Research Journal of Finance and Accounting, 4(1), $35-46$.

Manos R. (2002). Dividend policy and agency theory: Evidence on Indian firms (Finance and Development Research Programme, Working paper series Vol. 41). Retrieved from https://hummedia.manchester.ac.uk/ institutes/gdi/publications/workingpapers/archive/fd/fdwp41.pdf

Mehta, A. (2012). An empirical analysis of determinants of dividend policy - Evidence from the UAE companies. Global Review of Accounting and Finance, 3(1), 18-31.

Miller, H. M., \& Modigliani, F. (1961). Dividend policy, growth and the valuation of shares. Journal of Business, 34(4), 411-433.

Miller, M. H., \& Rock, K. (1985). Dividend policy under asymmetric information. The Journal of Finance, 40(4), 1031-1051.

Nachane, D. M. (2006). Econometrics: Theoretical foundations and empirical perspectives. New Delhi: Oxford University Press.

Osman, D., \& Mohammed, E. (2010). Dividend policy in Saudi Arabia. The International Journal of Business and Finance Research, 4(1), 99-114.

Rafique, M. (2012). Factors affecting dividend payout: Evidence from listed non-financial firms of Karachi stock exchange. Business Management Dynamics, 1(11), 76-92.

Ravindran, M., \& Kengatharan, L. (2020). Impact of dividend policy on return on assets: Evidence from listed non-financial firms in Sri Lanka. Sri Lankan Journal of Banking and Finance, 3(2), 72-89.

Redding, L. S. (1997). Firm size and dividend payouts. Journal of Financial Intermediation, 6(3), 224-248. 
Rehman, A. (2012). Determinants of dividend payout ratio: Evidence from Karachi Stock Exchange (KSE). Journal of Contemporary Issues in Business Research, 1(1), 20-27.

Rehman, A., \& Takumi, H. (2012). Determinants of dividend payout ratio: Evidence from Karachi Stock Exchange (KSE). Journal of Contemporary Issues in Business Research, 1(1), 20-27.

Rozeff, M. S. (1982). Growth, beta and agency costs as determinants of dividend payout ratios. Journal of Financial Research, 5(3), 249-259.

Shah, A. Z., Ullah, W., \& Hasnain, B. (2011). Impact of ownership structure on dividend policy of firm. In 2010 International Conference on E-Business, Management and Economics IPEDR (Vol. 3, pp. 22-26).

Thakur, B. P. S., \& Kannadhasan, M. (2018). Determinants of dividend payout of Indian manufacturing companies: A quantile regression approach. Journal of Indian Business Research, 10(4), 364-376.

Ullah, H., Fida, A., \& Khan, S. (2012). The impact of ownership structure on dividend policy evidence from emerging markets KSE-100 Index Pakistan. International Journal of Business and Social Science, 3(9), 298-307. 